\title{
THEORETICAL UNDERSTANDING OF MORPHOLOGICAL DISTRIBUTION OF HYDROGEN IN AMORPHOUS CALCIUM SILICATE HYDRATE
}

\author{
Chongsong Zhou ${ }^{\mathrm{a}, *, 10}$ and Lilin $\mathrm{Lu}^{\mathrm{b}}$ \\ aDepartment of Chemistry Biology \& Environmental Engineering, Hunan Provincial Key Laboratory of Xiangnan Rare-Precious \\ Metals Compounds and Applications, Xiangnan University, Chenzhou City, Hunan Province, People's Republic of China \\ ${ }^{\mathrm{b}}$ State Key Laboratory of Refractories and Metallurgy, Wuhan University of Science and Technology, Wuhan City, Hubei Province, \\ People's Republic of China
}

Recebido em 08/01/2020; aceito em 28/04/2020; publicado na web em 15/06/2020

\begin{abstract}
Determining the morphological distribution of hydrogen atoms in calcium silicate hydrate phase $(\mathrm{C}-\mathrm{S}-\mathrm{H})$ is of great concern but challenging. In this work, based on the stoichiometric composition of $(\mathrm{CaO})_{1.7}\left(\mathrm{SiO}_{2}\right)\left(\mathrm{H}_{2} \mathrm{O}\right)_{1.8}$, a series of amorphous $\mathrm{Ca}_{1.7} \bullet \mathrm{Si} \bullet(\mathrm{O})_{3,7-x} \cdot(\mathrm{OH})_{2 x} \cdot\left(\mathrm{H}_{2} \mathrm{O}\right)_{1.8-x}$ models are constructed using Monte Carlo method, where $x$ represents the molar number of dissociated $\mathrm{H}_{2} \mathrm{O}$ molecules $(x \in 0 \sim 1.8)$. A molecular dynamics simulation has been performed with the ClayFF force field. The analysis of $\mathrm{Q}^{\mathrm{n}}$, radial distribution function $(\mathrm{RDF})$, coordinate number $(\mathrm{CN})$, mean chain length (MCL), mean square displacement (MSD), elastic modulus $(M)$, and Young's modulus $(E)$ are used to explore the microstructure, hydrogen atom distribution and mechanical properties. The results demonstrate that the proportions of hydrogen atoms in $\mathrm{Ca}-\mathrm{OH}, \mathrm{Si}-\mathrm{OH}$, and $\mathrm{H}_{2} \mathrm{O}$ are about $26 \% \sim 45 \%$, 13\% 22\%, and 61\% 33\%, respectively. The calculated microstructure parameters and mechanical properties, especially for C-S-H models with $x$ of $0.7 \sim 1.2$, are in good agreement with those reported previously in theoretical and experimental works, indicative of the excellent rationality of our theoretical C-S-H models. The simulated results of this work provides a new strategy of constructing theoretical C-S-H model, which might be suitable for studying the doping behavior of metal oxides or metal salts in C-S-H.
\end{abstract}

Keywords: calcium silicate hydrate (C-S-H); morphological distribution; molecular dynamics simulation; hydrogen atoms; amorphous.

\section{INTRODUCTION}

As the core component of cement gels, Calcium-SilicateHydrated (C-S-H) accounts for $60 \% \sim 70 \%$ of the cement mass. The chemical composition of $\mathrm{C}-\mathrm{S}-\mathrm{H}$ can be expressed as $(\mathrm{CaO})_{1.7}\left(\mathrm{SiO}_{2}\right)\left(\mathrm{H}_{2} \mathrm{O}\right)_{1.8}$, determined by small-angle neutron diffraction and $x$-ray diffraction techniques. ${ }^{1}$ At least three types of hydrogen atoms in $\mathrm{C}-\mathrm{S}-\mathrm{H}$ (i.e., free $\mathrm{OH}$, confined $\mathrm{OH}$ and $\mathrm{H}_{2} \mathrm{O}$ ) were characterized by two-dimensional NMR technology, ${ }^{2,3}$ but their proportions in C-S-H remain unclear.

The coordination state between $\mathrm{OH}$ and $\mathrm{Si}$ (or $\mathrm{Ca}$ ) atoms in $\mathrm{C}-\mathrm{S}-\mathrm{H}$ is also arguable. Some experimental studies demonstrated that the percentage of hydrogen bonding between $\mathrm{SiO}_{4}$ and $\mathrm{SiO}_{3}-\mathrm{OH}$ was $38.14 \%{ }^{4}$ and the $\mathrm{Si}-\mathrm{OH}$ bond appear in $\mathrm{Q}^{1}$ or the non-bridged oxygen of $\mathrm{Q}^{2}{ }^{5}$ The $\mathrm{Si}-\mathrm{OH}$ content decreases with the increase of the mole ratio of $\mathrm{Ca}$ atoms to $\mathrm{Si}$ atoms $(\mathrm{C} / \mathrm{S})$ in $\mathrm{C}-\mathrm{S}-\mathrm{H} .{ }^{5} \mathrm{Si}-\mathrm{OH}$ bond disappears at high $\mathrm{Ca} / \mathrm{Si}$ ratio $(\mathrm{C} / \mathrm{S}>1.2)$, while $\mathrm{Ca}-\mathrm{OH}$ bond start appearing at high $\mathrm{C} / \mathrm{S}$ ratio $(\mathrm{C} / \mathrm{S}>1.3) .{ }^{6,7}$ Computational study found that the $\mathrm{Si}-\mathrm{O} \cdots \mathrm{Ca}$ bond might hydrolysis to form a $\mathrm{Si}-\mathrm{OH}$ bond and a $\mathrm{Ca}-\mathrm{OH}$ bond at $\mathrm{C} / \mathrm{S}$ ratio of $1.3,{ }^{8}$ and the number of $\mathrm{Si}-\mathrm{OH}$ bonds per $\mathrm{Si}$ atom was about 0.25 and 0.1 when the $\mathrm{C} / \mathrm{S}$ ratio equals to at 1.4 and 2.0, respectively. ${ }^{9}$

The molecular simulation technology provides a new method to explore the bonding state of hydrogen atoms in $\mathrm{C}-\mathrm{S}-\mathrm{H}$ on the atomic scale. It is critical and challenging to construct a resonable theoretical $\mathrm{C}-\mathrm{S}-\mathrm{H}$ model to perform theoretical simulations. In previous works, two C-S-H models were used to investigate the microstructure and mechanical properties of cement paste. One is sandwiched and layer-ordered C-S-H model based on Tobermorite/Calcium hydroxyl (T/CH) or Tobermorite/Jennite (T/J) crystal, ${ }^{10}$ the other is amorphous
C-S-H model formed from the polymerization of $\mathrm{Si}(\mathrm{OH})_{4}, \mathrm{Ca}(\mathrm{OH})_{2}$ and $\mathrm{H}_{2} \mathrm{O} .{ }^{9}$

The former has successfully elucidated the experimental results such as the mechanical properties of C-S-H and the effect of C/S ratio on mechanical properties, and has been proved to be suitable for studying the surface structure and the properties of C-S-H. ${ }^{11,12}$ However, the infinitely linked $\mathrm{SiO}_{4}$ tetrahedron chains in this $\mathrm{C}-\mathrm{S}-\mathrm{H}$ model are inconsistent with the fact that the dimers and pentamers are dominant in the actual cement gels. Pellenq et al.${ }^{13}$ manually removed some $\mathrm{SiO}_{2}$ units from the T/CH models to match the experimental $\mathrm{Q}^{\mathrm{n}}$ distribution, the density and elastic modulus of C-S-H. Lack of universality is the main disadvantage of this method, which relies heavily on individual expertise and experience.

Dolado et al. ${ }^{9}$ has used the latter model to simulate the formation process of C-S-H and hydrogen bonding that was observed in the experimental research, however, this theoretical work led to excessive mole ratio of water molecules to $\mathrm{Si}$ atoms $(\mathrm{H} / \mathrm{S})$, which influenced the polymerization of $\mathrm{SiO}_{4}$ tetrahedra and resulted in excessively high $\mathrm{Q}^{0}$ at $\mathrm{C} / \mathrm{S}=2.0$.

As proved by previous works, theoretical study based on an ideal model without artificial modification was desirable for understanding the experimental results about the microstructure and mechanical properties of C-S-H. In this work, molecular dynamics simulation was performed on the basis of amorphous $\mathrm{C}-\mathrm{S}-\mathrm{H}$ models, which was derived from the random combination of some atomic units such as $\mathrm{Ca}, \mathrm{Si}, \mathrm{O}, \mathrm{OH}$, and $\mathrm{H}_{2} \mathrm{O} .{ }^{9}$ During the molecular dynamics studies, ClayFF force field parameters ${ }^{14,15}$ were selected to simulate the geometry of the C-S-H model. The microstructure and mechanical properties were analyzed to elucidate the morphological distribution of hydrogen atoms in C-S-H. 


\section{COMPUTATIONAL DETAILS}

Based on the basic atomic units including $\mathrm{Ca}, \mathrm{Si}, \mathrm{O}, \mathrm{OH}$, and $\mathrm{H}_{2} \mathrm{O}$, the cubic models of $\mathrm{Ca}_{17} \cdot \mathrm{Si} \bullet(\mathrm{O})_{3.7-x} \bullet(\mathrm{OH})_{2 x} \bullet\left(\mathrm{H}_{2} \mathrm{O}\right)_{1.8-x}$ ( $x$ represents the molar number of dissociated $\mathrm{H}_{2} \mathrm{O}$ molecules, $x \in 0 \sim 1.8, \mathrm{C} / \mathrm{S}=1.7$, $\mathrm{H} / \mathrm{S}=1.8$ and a density of $2.604 \mathrm{~g} \mathrm{~cm}^{-3}$ in the reference) $)^{1}$ are constructed by using Monte-Carlo method in Materials Studio software. ${ }^{16}$ The detailed numbers of basic atomic units in $\mathrm{C}-\mathrm{S}-\mathrm{H}$ are shown in Table 1.

The ClayFF force field ${ }^{14}$ is used to calculate the structure and properties of $\mathrm{C}-\mathrm{S}-\mathrm{H}$ in this work. ClayFF is a set of parameters obtained by fitting a set of simple and characteristic hydrated phases, so that its parameters, like CementFF, ${ }^{17}$ have very good transferability. ${ }^{15}$ Therefore, it is very beneficial to the bonding and exchange processes between these basic atomic units in CSH model. Moreover, ClayFF has been used to describe the bulk structure of various simple hydroxide and oxyhydroxide phases ${ }^{15}$ and the surface behaviors of alkylated quartz ${ }^{18}$ successfully.

In ClayFF, the total potential energy comprises four types of interaction as the equation 1 :

$$
E_{\mathrm{total}}=E_{\mathrm{coul}}+E_{\mathrm{VDW}}+E_{\mathrm{bondstretch}}+E_{\text {anglebend }}
$$

where $E_{\text {bondstretch }}$ only involves the elastic vibration of $\mathrm{O}-\mathrm{H}$ in $\mathrm{OH}$ and $\mathrm{H}_{2} \mathrm{O}, E_{\text {anglebend }}$ only considers the bending vibration of $\mathrm{H}-\mathrm{O}-\mathrm{H}$ in $\mathrm{H}_{2} \mathrm{O}$, and the remaining potential energy is described by the non-bonded Coulomb (short range) and van der Waals (long range) interaction. The detailed parameters of the ClayFF force field are listed in Table $1 \mathrm{~S}$ in Supporting Information.

The atomic types of ClayFF force field are assigned as follows. The cah of 1.0500 charge is used for the $\mathrm{Ca}$ atoms, and the st of 2.1000 charge is used for $\mathrm{Si}$ atoms. The oh of -0.9500 charge, the $\mathrm{O}^{*}$ of -0.8200 charge and the ob of -1.0500 charge is used for $\mathrm{O}$ atoms in $\mathrm{OH}$ group, $\mathrm{H}_{2} \mathrm{O}$ and the other part, respectively. The ho of 0.4250 charge and the $\mathrm{h}^{*}$ of 0.4100 charge is used for $\mathrm{H}$ atoms in $\mathrm{OH}$ and $\mathrm{H}_{2} \mathrm{O}$, respectively. The species such as $\mathrm{CaO}, \mathrm{SiO}_{2}, \mathrm{Ca}(\mathrm{OH})_{2}$ and $\mathrm{Si}(\mathrm{OH})_{4}$ maintain electrical neutrality during ion exchange. The parameters have been used to fully optimize the crystal structure of Jennite, ${ }^{19}$ and the average relative deviation between theoretical and experimental unit cell parameters is about $0.39 \%$, indicative of the applicability of the ClayFF force field and the effectiveness of atomic type assignment method in $\mathrm{C}-\mathrm{S}-\mathrm{H}$ simulation.

These C-S-H models are relaxed under NVT ensemble with a step size of $0.2 \mathrm{fs}$ at $298.15 \mathrm{~K}$. The nose-hoover method ${ }^{20}$ with Q-ratio of 0.10 is selected to control temperature. The electrostatic and van der Waals interaction are calculated by Ewald addition method. ${ }^{21}$ The energy convergence standard is set to $0.01 \mathrm{kcal} \mathrm{mol}^{-1}$. The $\mathrm{Q}^{\mathrm{n}}$ change is used to evaluate the adequacy of simulation time (see Table $2 \mathrm{~S}$ ). The mean absolute deviations of $\mathrm{Q}^{\mathrm{n}}$ between $1000 \mathrm{ps}$ simulation and
100 ps simulation are only $1.42 \%$ and $1.32 \%$ for $x=0.4$ and $x=1.5$ $\mathrm{C}-\mathrm{S}-\mathrm{H}$ model, respectively, indicating that $100 \mathrm{ps}$ is sufficient for molecular dynamics (MD) simulations. Therefore, the trajectory of 100 ps simulation is used to analyze the structure parameters $\left(\mathrm{Q}^{\mathrm{n}}\right.$, $\mathrm{RDF}$, and $\mathrm{CN}$ ) and elastic modulus ( $M)$.

The C-S-H trajectory files after MD simulation are optimized using Discover software, and then the mechanical properties are calculated using ClayFF force field in GULP program. ${ }^{16}$ The mean modulus of C-S-H structures at the last $10 \mathrm{ps}$ is reported in this study. All simulations are performed in Material Studio software package ${ }^{16}$ and the statistical results of $\mathrm{Q}^{\mathrm{n}}, \mathrm{RDF}$, and $\mathrm{CN}$ are calculated by using self-programming codes (see Supporting Information). The distance of 3.2 angstroms is set as the threshold for chain formation via $\mathrm{SiO}_{4}$ tetrahedra polymerization.

\section{RESULTS AND DISCUSSION}

\section{Polymerization of $\mathrm{SiO}_{4}$ chain and $\mathrm{Q}^{\mathrm{n}}$}

The polymerization of $\mathrm{SiO}_{4}$ forming chain, which plays a critical role in cement hydration, is characterized by the $\mathrm{Q}^{\mathrm{n}}$ for the C-S-H models with different $x$ value, the evolution of $\mathrm{Q}^{\mathrm{n}}$ has been shown in Figure 1.

As for the polymerization process, the simulation results show that all $\mathrm{Si}$ atoms can form $\mathrm{SiO}_{4}$ tetrahedra and thus generate a longer $\mathrm{SiO}_{4}$ chain. All $\mathrm{Ca}$ atoms are dispersed randomly around $\mathrm{SiO}_{4}$ chains to form layered C-S-H structure (see Figure 1S). ${ }^{10}$ The evolution of $\mathrm{Q}^{\mathrm{n}}$ shows that the polymerization process of $\mathrm{SiO}_{4}$ in $\mathrm{C}-\mathrm{S}-\mathrm{H}$ can quickly reach equilibrium state within $1 \mathrm{ps}$, whereas this process was reported to more than $500 \mathrm{ps}$ in previous work (see $h$ in Figure 1). ${ }^{9}$ This indicates that the randomly stacked C-S-H model based on the basic atomic units can quickly reach equilibrium state. This can be attributed to the rapid migration of these ionic basic units with ClayFF force field, just as all MD simulations reach convergence in structure within 20 ps. ${ }^{14,15}$

In order to investigate the stability of $\mathrm{Q}^{\mathrm{n}}$ in random $\mathrm{C}-\mathrm{S}-\mathrm{H}$ models, ten original C-S-H models $(x=1.0)$ are randomly constructed using the same modeling method, and then are relaxed under the same simulation conditions. All standard deviations of $\mathrm{Q}^{\mathrm{n}}$ being within $2.69 \%$ indicates the reliable reproducibility of the modeling method (see Table $3 \mathrm{~S}$ in Supporting Information).

The calculated $\mathrm{Q}^{0}, \mathrm{Q}^{1}, \mathrm{Q}^{2}$, and $\mathrm{Q}^{3}+\mathrm{Q}^{4}$ range from $14.1 \%$ to $44.5 \%$, from $54.7 \%$ to $36.4 \%$, from $30.7 \%$ to $14.6 \%$, and from $0.4 \%$ to $1.5 \%$, respectively (Figure 2). In the experimental works reported by Rawal ${ }^{2}$ and Mendes, ${ }^{22}$ the values of $\mathrm{Q}^{0}, \mathrm{Q}^{1}, \mathrm{Q}^{2}, \mathrm{Q}^{3}+\mathrm{Q}^{4}$ are within $36 \% \sim 41 \%$, 40\% 39\%, 24\% 20\%, 0\%, respectively. The computational results also agree with the experimental range of $35-19 \%$ for $\mathrm{Q}^{0}, 38 \% \sim 45 \%$ for $\mathrm{Q}^{1}$, and $27 \% \sim 37 \%$ for $\mathrm{Q}^{2}$ in the hydrated products after 3 28 days of $\mathrm{C}_{3} \mathrm{~S}$ hydration. ${ }^{23}$

Table 1. The number of basic atomic units in $\mathrm{Ca}_{1.7} \bullet \mathrm{Si} \bullet(\mathrm{O})_{3.7-x} \cdot(\mathrm{OH})_{2 x} \bullet\left(\mathrm{H}_{2} \mathrm{O}\right)_{1.8-x}$

\begin{tabular}{|c|c|c|c|c|c|c|}
\hline$x^{a}$ & $\mathrm{Ca}$ & $\mathrm{Si}$ & $\mathrm{O}$ & $\mathrm{OH}$ & $\mathrm{H}_{2} \mathrm{O}$ & Density $^{1}$ \\
\hline 0.0 & 340 & 200 & 740 & 0 & 360 & 2.604 \\
\hline 0.4 & 340 & 200 & 660 & 160 & 280 & 2.604 \\
\hline 0.7 & 340 & 200 & 600 & 280 & 220 & 2.604 \\
\hline 1.0 & 340 & 200 & 540 & 400 & 160 & 2.604 \\
\hline 1.2 & 340 & 200 & 500 & 480 & 120 & 2.604 \\
\hline 1.5 & 340 & 200 & 440 & 600 & 60 & 2.604 \\
\hline 1.7 & 340 & 200 & 400 & 680 & 20 & 2.604 \\
\hline
\end{tabular}

${ }^{\mathrm{a}} x$ is the molar number of dissociated water molecules, $x=0 \sim 1.8$. 

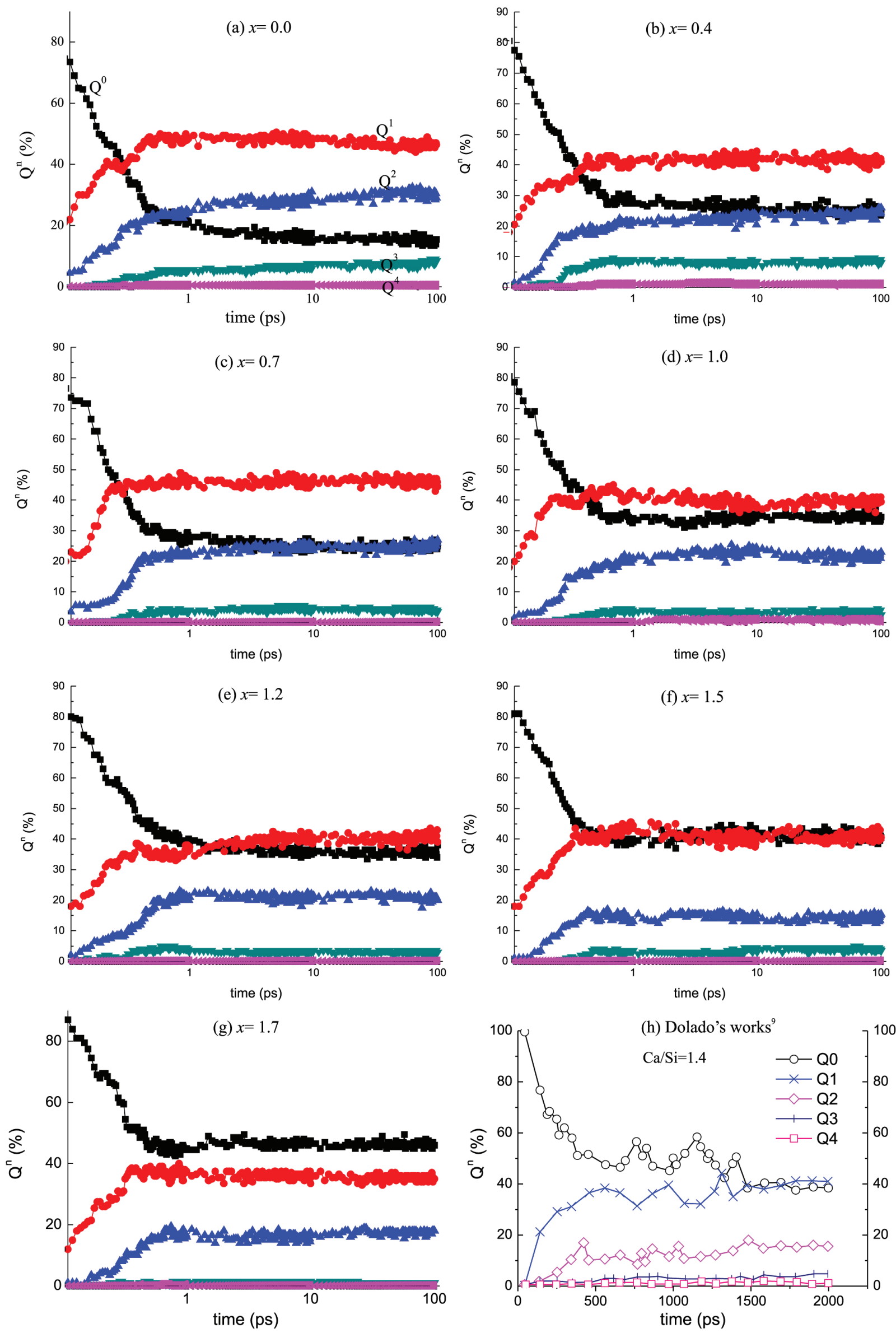

Figure 1. The evolution of $Q^{n}$ in $C-S-H$ 
Relative to the similar theoretical range of $39.3 \% \sim 62.0 \%$ for $\mathrm{Q}^{0}$, $40 \% \sim 32 \%$ for $\mathrm{Q}^{1}$, and $16 \% \sim 4 \%$ for $\mathrm{Q}^{2}$ in C-S-H models with $\mathrm{C} / \mathrm{S}$ ratios of 1.4 2.0, ${ }^{9}$ there are slightly less $\mathrm{Q}^{0}$ and more $\mathrm{Q}^{2}$ in this work, indicative of the higher polymerization degree of $\mathrm{SiO}_{4}$ due to a reasonable $\mathrm{H} / \mathrm{S}$ ratio. However, there are slightly more $\mathrm{Q}^{0}$ and less $\mathrm{Q}^{1}$ than the results of $12 \%$ for $\mathrm{Q}^{0}, 67 \%$ for $\mathrm{Q}^{1}$, and $21 \%$ for $\mathrm{Q}^{2}$ in the cCSH models $(\mathrm{C} / \mathrm{S}=1.7)^{24}$ and the results of $10 \%$ for $\mathrm{Q}^{0}, 67 \%$ for $\mathrm{Q}^{1}$, and $23 \%$ for $\mathrm{Q}^{2}{ }^{13}$ Both of their C-S-H models were characterized by highly hydration and dominant $\mathrm{Q}^{1}$ because of the artificial remove of $\mathrm{SiO}_{2}$ based on Tobermorite.

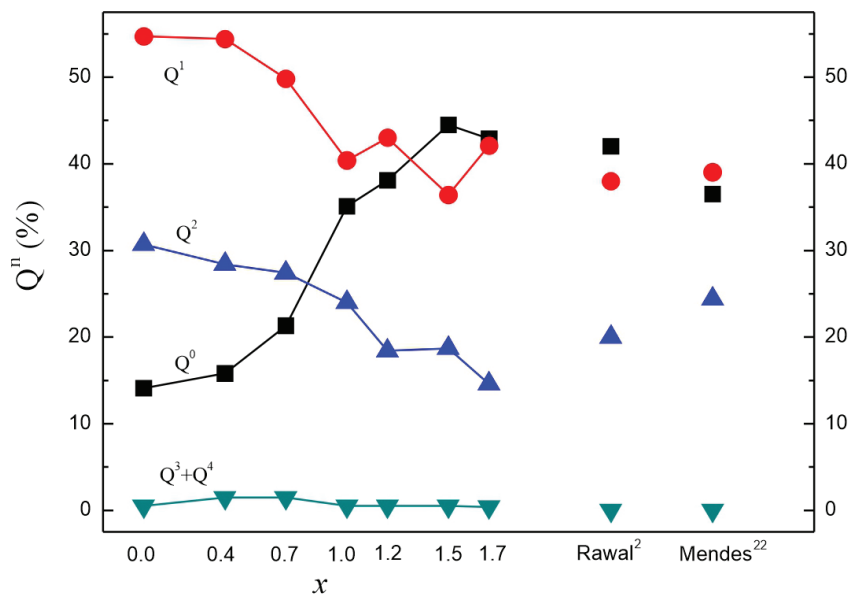

Figure 2. Effect of $x$ on $Q^{n}$

The variation of individual $\mathrm{Q}^{\mathrm{n}}$ in this work is consistent with the evolution process of $\mathrm{Q}^{\mathrm{n}}{ }^{9}{ }^{9}$ where the $\mathrm{Q}^{0}$ decreases while the $\mathrm{Q}^{1}$ and $\mathrm{Q}^{2}$ increase with simulation time. Meanwhile, the value of $\mathrm{Q}^{1}$ is always greater than that of $\mathrm{Q}^{2}$ regardless of $x$. However, the $\mathrm{Q}^{0}$ decreases with the increase of $x$, for instance, there being $\mathrm{Q}^{0}<\mathrm{Q}^{2}<\mathrm{Q}^{1}$ at $x=0$, while the $\mathrm{Q}^{0}$ being equivalent to the $\mathrm{Q}^{2}$ at $x=0.7$, and even the $\mathrm{Q}^{0}$ being equivalent to the $\mathrm{Q}^{1}$ at $x>1.2$ (Figure 2). It indicates the decrease of water molecules and bridged oxygen atoms in $\mathrm{C}-\mathrm{S}-\mathrm{H}$ with increasing $x$ does not conducive to the lengthening of $\mathrm{SiO}_{4}$ chains.

According to the mean chain length $=2 \times\left(1+\mathrm{Q}^{2} / \mathrm{Q}^{1}\right)$, the calculated MCL within 2.69 3.19 are in excellent agreement with the experimental results of 3.05 for Portland cement slurry ${ }^{2}$ and of 3.25 for cement gels doped by slag, ${ }^{22}$ indicating that the dimers and pentamers of $\mathrm{SiO}_{4}$ chains are dominant in this $\mathrm{C}-\mathrm{S}-\mathrm{H}$ governed by a $3 n-1$ rule.

\section{Microstructural information of C-S-H models}

The radial distribution function (RDF) and coordination number $(\mathrm{CN})$ have been calculated to understand the microstructure of $\mathrm{C}-\mathrm{S}-\mathrm{H}$. The computational results show that the RDF and $\mathrm{CN}$ between $\mathrm{Ca}$ (or $\mathrm{Si}$ ) and total $\mathrm{O}$ atoms hardly vary with increasing $x$, hence the RDF and CN of C-S-H only at $x=1.0$ is shown in Figure 3 . It can be seen from Figure 3 that there exists a clearly localized interaction at an average distance of $1.57 \AA$ for $\mathrm{Si}-\mathrm{O}$ bond and of $2.47 \AA$ for $\mathrm{Ca}-\mathrm{O}$ bond. They reproduce the $1.62 \AA$ of $\mathrm{Si}-\mathrm{O}$ and 2.38 $\AA$ of $\mathrm{Ca}-\mathrm{O}$ for Tobermorite and Jennite, and the $1.60 \AA$ of $\mathrm{Si}-\mathrm{O}$ and $2.45 \AA$ of $\mathrm{Ca}-\mathrm{O}$ for cCSH models. ${ }^{13}$ Relatively to cCSH models, there is a narrower $\mathrm{Si}-\mathrm{O}$ peak on the RDF curve in this model, indicating that the bonding between $\mathrm{Si}$ and $\mathrm{O}$ atoms is more orderly on the short range. The $\mathrm{CN}$ of $\mathrm{Si}-\mathrm{O}$ and $\mathrm{Ca}-\mathrm{O}$ in the first coordinating layer is 4.0 and 6.0, respectively, indicative of the formation of $\left[\mathrm{SiO}_{4}\right]$ tetrahedron and $\left[\mathrm{CaO}_{6}\right]$ octahedron in this C-S-H. Therefore, the random C-S-H model based on basic atomic units can reappear well the experimental and theoretical microstructure of $\mathrm{C}-\mathrm{S}-\mathrm{H}$.

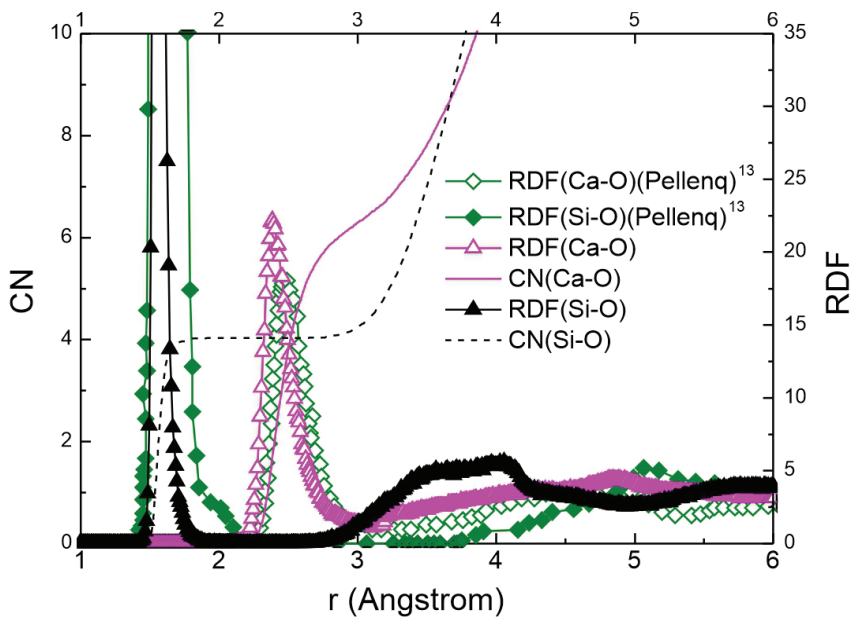

Figure 3. The Radial distribution function $(R D F)$ and coordinate number $(C N)$ in the $C-S-H$ of $x=1.0$

It can be also found from Figure 3 an obvious long-range interaction between $\mathrm{Si}$ and $\mathrm{O}$ atoms in the range of $3 \sim 4.2 \AA$, which did not emerge in the cCSH models. ${ }^{13}$ The RDF and $\mathrm{CN}$ between $\mathrm{Si}$ and $\mathrm{O}$ atoms (including $\mathrm{O}_{\mathrm{b}}, \mathrm{O}_{\mathrm{h}}$, and $\mathrm{O}_{\mathrm{w}}$ ) are calculated to explore their long-range interaction as seen in Figure 4. In the first coordination layer, the $\mathrm{CN}$ is 2.7 for $\mathrm{Si}-\mathrm{O}_{\mathrm{b}}, 1.2$ for $\mathrm{Si}-\mathrm{O}_{\mathrm{h}}$, and 0.1 for $\mathrm{Si}-\mathrm{O}_{\mathrm{w}}$, indicating that the major of $\mathrm{Si}$ atoms coordinate with the bridged $\mathrm{O}$ atoms and a small part of $\mathrm{Si}$ atoms can form $\mathrm{Si}-\mathrm{OH}$ bond, while the $\mathrm{Si}$ atoms hardly interact with the $\mathrm{O}$ atoms of water molecules. There is an inconsiderable second coordination layer between $\mathrm{Si}$ and $\mathrm{O}$ atoms in the range of 3.0 4.5 $\AA$. The RDF peak at $3.5 \AA$ between $\mathrm{Si}$ and the $\mathrm{O}$ atoms of $\mathrm{OH}$ is closer than that of $4.0 \AA$ between $\mathrm{Si}$ and the bridged $\mathrm{O}$ atoms. The total $\mathrm{CN}$ of $\mathrm{Si}-\mathrm{O}$ is 16.0 within $4.2 \AA$ (in Figure 3) included 8.0 of $\mathrm{Si}-\mathrm{O}_{\mathrm{b}}, 6.0$ of $\mathrm{Si}-\mathrm{O}_{\mathrm{h}}$, and 2.0 of $\mathrm{Si}-\mathrm{O}_{\mathrm{w}}$ (in Figure 4). Therefore, the $\mathrm{CN}$ is 4.8 for $\mathrm{Si}_{-} \mathrm{O}_{\mathrm{h}}$ and 1.9 for $\mathrm{Si}-\mathrm{O}_{\mathrm{w}}$ in the second layer after subtracting their $\mathrm{CN}$ in the first layer, indicating that the number of hydrogen bonds is about 5 for the $\mathrm{Si}_{(1)}-\mathrm{O}_{\mathrm{b}(2)} \cdots \mathrm{H}_{\mathrm{h}(3)}-\mathrm{O}_{\mathrm{h}(4)}$ and $\mathrm{Si}_{(1)}-\mathrm{O}_{\mathrm{h}(2)}-\mathrm{H}_{\mathrm{h}(3)} \cdots \mathrm{O}_{\mathrm{h}(4)}$ interaction and about 2 for the $\mathrm{Si}_{(1)}-\mathrm{O}_{\mathrm{b}(2)} \cdots \mathrm{H}_{\mathrm{w}(3)}-\mathrm{O}_{\mathrm{w}(4)}$ and $\mathrm{Si}_{(1)}-\mathrm{O}_{\mathrm{h}(2)}-\mathrm{H}_{\mathrm{h}(3)} \cdots \mathrm{O}_{\mathrm{w}(4)}$ interaction in the range of 3.0 4.2 $\AA$. The smaller mean square displacement (MSD) of water molecules in C-S-H models can also indicate the existence of these hydrogen bonds (See Figure 2S).

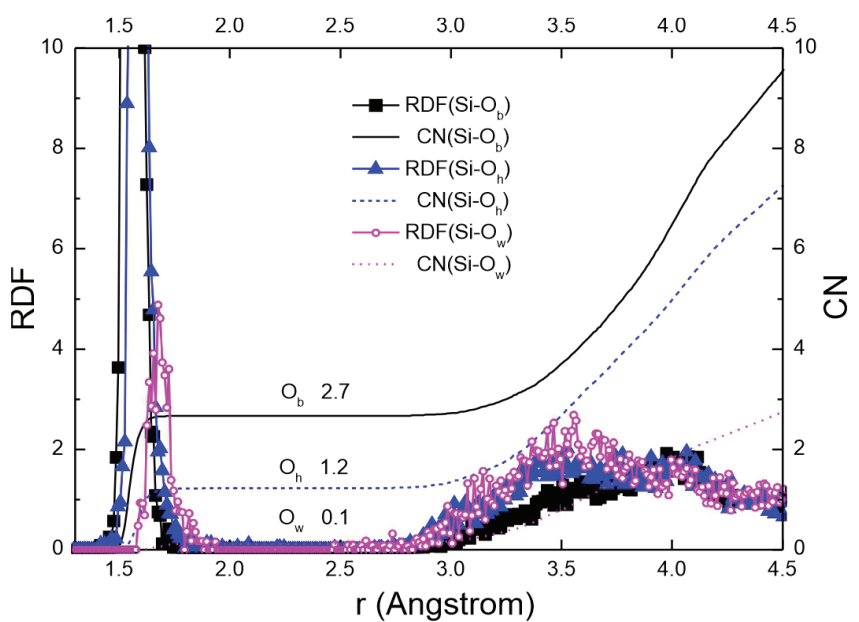

Figure 4. The RDF and $C N$ between $S i$ and three types of $O$ atoms in the $C-S-H$ of $x=1.0$ 


\section{Bonding of $\mathrm{OH}$ with $\mathrm{Si}$ (or Ca)}

In order to investigate in detail the bonding of $\mathrm{OH}$ and $\mathrm{Si}$ (or $\mathrm{Ca}$ ), their $\mathrm{CN}$ and proportions of various $\mathrm{OH}$ in $\mathrm{C}-\mathrm{S}-\mathrm{H}$ are shown in Table 2 (except for the C-S-H model at $x=0$ ). It can be seen from Table 2, the ratio of the $\mathrm{CN}$ between $\mathrm{Si}$ (or $\mathrm{Ca}$ ) and $\mathrm{O}_{\mathrm{h}}$ to the $\mathrm{CN}$ between $\mathrm{Si}$ (or $\mathrm{Ca}$ ) and total $\mathrm{O}$ increases with the $x$ (see column $d$ ). Therefore, the percentage of $\mathrm{Si}$ (or $\mathrm{Ca}$ ) linking with $\mathrm{OH}$ gets bigger ( see column $c$ ). Similarly, the number of $\mathrm{Si}-\mathrm{OH}$ (or $\mathrm{Ca}-\mathrm{OH}$ ) bond increases with increasing $x$, and the average number increases from 1.29 to 2.34 per $\mathrm{Si}$ atom for $\mathrm{Si}-\mathrm{OH}$ bond while it ranges from 1.34 to 2.96 per $\mathrm{Ca}$ atom for $\mathrm{Ca}-\mathrm{OH}$ bond (see column $e$ ).

Based on the analysis of $\mathrm{CN}$ and charge balance, their distribution ratios of $\mathrm{OH}$ between $\mathrm{Si}-\mathrm{OH}$ and $\mathrm{Ca}-\mathrm{OH}$ are listed in Table 2. Regardless of the $x$ in the C-S-H models, there are about $31 \%$ of $\mathrm{OH}$ linked to $\mathrm{Si}$ atoms, and each $\mathrm{OH}$ is localized around only one $\mathrm{Si}$ atom. Whereas about $67 \%$ of $\mathrm{OH}$ will be interacted with $\mathrm{Ca}$ atoms, and two $\mathrm{Ca}$ atoms share one $\mathrm{OH}$ group on average. It is consistent with the results that most of the $\mathrm{OH}$ interacts with $\mathrm{Ca}$ atoms in C-S-H (see Figure 3S). ${ }^{2,5}$ Moreover, the fracture of $\mathrm{SiO}_{4}$ chain in cement pastes may cause the dissociation of $\mathrm{H}_{2} \mathrm{O}$ molecules to form the $\mathrm{Si}-\mathrm{OH}$ and $\mathrm{Ca}-\mathrm{OH},{ }^{13}$ and the thermogravimetric results have also shown that the weightless process occurred at $200 \sim 300{ }^{\circ} \mathrm{C}$ corresponds to the dehydration process of $\mathrm{Si}-\mathrm{OH}$ bonds. ${ }^{25,26}$ Therefore, it is reasonable to emerge $\mathrm{Si}-\mathrm{OH}$ in $\mathrm{C}-\mathrm{S}-\mathrm{H}$.

The $\mathrm{Ca}-\mathrm{OH} / \mathrm{Ca}$ ratio ranges from 0.33 to 1.37 in this work (see column $j$ ), indicating that the charges of about $15-64 \% \mathrm{Ca}$ atoms in $\mathrm{C}-\mathrm{S}-\mathrm{H}$ are balanced by the $\mathrm{OH}$ groups. Similarly, the experimental $\mathrm{Ca}-\mathrm{OH} / \mathrm{Ca}$ ratio of 0.46 means the charges of $23 \% \mathrm{Ca}$ atoms being balanced by the $\mathrm{OH}$ groups for the $\mathrm{C}-\mathrm{S}-\mathrm{H}$ with a $\mathrm{C} / \mathrm{S}$ ratio of 1.7. ${ }^{27}$ The simulated $\mathrm{Ca}-\mathrm{OH} / \mathrm{Ca}$ ratios of $0.55 \sim 0.95$ when $x=0.7 \sim 1.2$ are closely consistent with their experimental ratio of 0.46 , and this subtle difference can be attributed to a different $\mathrm{H} / \mathrm{S}$ ratio (1.8 vs 1.34).
The ratios of $\mathrm{H}$ (or $\mathrm{O}$ ) atoms in $\mathrm{Ca}-\mathrm{OH}, \mathrm{Si}-\mathrm{OH}$, and $\mathrm{H}_{2} \mathrm{O}$ to total $\mathrm{H}$ (or $\mathrm{O}$ ) atoms are calculated to study their coordination status in C-S-H as shown in Table 3. Based on the data of $\mathrm{O}$ atom distribution, ${ }^{28}$ the ratio of $\mathrm{H}$ atoms in $\mathrm{Ca}-\mathrm{OH}, \mathrm{Si}-\mathrm{OH}$, and $\mathrm{H}_{2} \mathrm{O}$ is in the range of $34 \% \sim 46 \%, 9 \% \sim 25 \%$, and $31 \% \sim 54 \%$, respectively, while it is $15 \% \sim 64 \%, 7 \% \sim 29 \%$, and $7 \% \sim 78 \%$ in this simulation, respectively. Obviously, the larger simulated distribution range of $\mathrm{H}$ atoms covers the experimental results obtained from the various $\mathrm{C}-\mathrm{S}-\mathrm{H}$ samples with a $\mathrm{C} / \mathrm{S}$ ratio from 1.54 to 1.85 . An amorphous C-S-H model of $x=0.4 \sim 1.7,0.7 \sim 1.5$, and $0.7 \sim 1.2$ is suitable for the precise demonstration of $\mathrm{Si}-\mathrm{OH}, \mathrm{Ca}-\mathrm{OH}$, and $\mathrm{H}_{2} \mathrm{O}$, respectively. Therefore, it is suggested that a wide applicability of this modeling.

Based on the above discussion of the $\mathrm{CN}$ and charge balance between $\mathrm{OH}$ and $\mathrm{Si}$ (or $\mathrm{Ca}$ ), it can be concluded that the $\mathrm{C}-\mathrm{S}-\mathrm{H}$ models of $x=0.7 \sim 1.2$ may completely reproduce the distribution of three types of $\mathrm{OH}$ in actual C-S-H.

\section{Mechanical properties of C-S-H}

The higher-order properties such as elastic constants $(E)$ are often used to investigate the microstructure of materials. The calculated mechanical properties of C-S-H models are shown in Table 4.

The calculated elastic modula $(M)$ and Young's modula $(E)$ of C-S-H models vary within 53 69 GPa and 48 63 GPa, respectively. For the C-S-H model ( $x=1.2$ ), both $M$ and $E$ are exactly consistent with the values reported in theoretical works ${ }^{13,29}$ and experimental works..$^{30}$ In addition, these simulated elastic modula of C-S-H models $(\mathrm{C} / \mathrm{S}=1.7)$ are closer to that of Jennite $(\mathrm{C} / \mathrm{S}=1.5)$, but are far from that of Tobermorite-14 $(\mathrm{C} / \mathrm{S}=0.83)$.

\section{Reasonable range of $x$}

It can be concluded that the effects of $x$ value in $\mathrm{C}-\mathrm{S}$-H models

Table 2. (a) The bonding between $\mathrm{Si}$ and $\mathrm{OH}$; (b) The bonding between $\mathrm{Ca}$ and $\mathrm{OH}$

(a)

\begin{tabular}{ccccccccc}
\hline$x^{\mathrm{a}}$ & $\mathrm{OH} / \mathrm{H}(\%)^{\mathrm{b}}$ & $\mathrm{Si}-\mathrm{OH} / \mathrm{Si}(\%)^{\mathrm{c}}$ & $\mathrm{CN}\left(\mathrm{Si}-\mathrm{O}_{\mathrm{h}}\right) / \mathrm{CN}(\mathrm{Si}-\mathrm{O})^{\mathrm{d}}$ & $\mathrm{Si}_{-} \mathrm{OH}$ per Si & $\mathrm{Si}_{-} \mathrm{OH} / \mathrm{OH}(\%)^{\mathrm{f}}$ & $\mathrm{OH}_{-} \mathrm{Si}^{\mathrm{g}}$ & $\mathrm{SiOH} / \mathrm{OH}(\%)^{\mathrm{h}}$ & $\mathrm{Si}-\mathrm{OH} / \mathrm{H}^{\mathrm{i}}$ \\
\hline 0.4 & 22 & 37 & 0.12 & 1.29 & 59 & 1.00 & 29 & 0.07 \\
0.7 & 39 & 59 & 0.22 & 1.50 & 63 & 1.02 & 31 & 0.13 \\
1.0 & 56 & 74 & 0.33 & 1.81 & 66 & 1.01 & 33 & 0.18 \\
1.2 & 67 & 78 & 0.38 & 1.93 & 62 & 1.02 & 31 & 0.21 \\
1.5 & 83 & 89 & 0.47 & 2.11 & 61 & 1.02 & 31 & 0.25 \\
1.7 & 94 & 90 & 0.53 & 2.34 & 61 & 1.01 & 31 & 0.29 \\
\hline
\end{tabular}

(b)

\begin{tabular}{|c|c|c|c|c|c|c|c|c|c|}
\hline$x^{\mathrm{a}}$ & $\mathrm{OH} / \mathrm{H}(\%)^{\mathrm{b}}$ & $\mathrm{Ca}-\mathrm{OH} / \mathrm{Ca}(\%)^{\mathrm{c}}$ & $\mathrm{CN}\left(\mathrm{Ca}-\mathrm{O}_{\mathrm{h}}\right) / \mathrm{CN}(\mathrm{Ca}-\mathrm{O})^{\mathrm{d}} \mathrm{C}$ & $\mathrm{Ca}-\mathrm{OH}$ per $\mathrm{Ca}^{\mathrm{e}}$ & $\mathrm{Ca}-\mathrm{OH} / \mathrm{OH}(\%)^{\mathrm{f}}$ & $\mathrm{OH}_{-} \mathrm{Ca}^{\mathrm{g}}$ & $\mathrm{CaOH} / \mathrm{OH}(\%)^{\mathrm{h}}$ & $\mathrm{Ca}-\mathrm{OH} / \mathrm{H}^{\mathrm{i}}$ & $\mathrm{Ca}-\mathrm{OH} / \mathrm{Ca}$ \\
\hline 0.4 & 22 & 52 & 0.12 & 1.34 & 99 & 2.10 & 69 & 0.15 & 0.33 \\
\hline 0.7 & 39 & 71 & 0.19 & 1.61 & 99 & 2.05 & 67 & 0.26 & 0.55 \\
\hline 1.0 & 56 & 82 & 0.26 & 1.93 & 99 & 2.04 & 66 & 0.37 & 0.77 \\
\hline 1.2 & 67 & 88 & 0.34 & 2.30 & 98 & 2.11 & 67 & 0.45 & 0.95 \\
\hline 1.5 & 83 & 94 & 0.41 & 2.62 & 99 & 2.05 & 68 & 0.57 & 1.21 \\
\hline 1.7 & 94 & 97 & 0.48 & 2.96 & 99 & 2.07 & 68 & 0.64 & 1.37 \\
\hline \multicolumn{9}{|c|}{ The experimental result of $\mathrm{C}-\mathrm{S}-\mathrm{H}$ of $\mathrm{C} / \mathrm{S}=1.7$ and $\mathrm{H} / \mathrm{S}=1.34$ by Thomas et al. ${ }^{27}$} & 0.46 \\
\hline
\end{tabular}

${ }^{\mathrm{a}}$ The molar number of dissociated $\mathrm{H}_{2} \mathrm{O}$ molecules in C-S-H models; ${ }^{\mathrm{b}}$ The percentage of $\mathrm{H}$ atoms in $\mathrm{OH}$ to total $\mathrm{H}$ atoms, \%; $\mathrm{c}$ The percentage of $\mathrm{Si}$ (or Ca) atoms formed $\mathrm{Si}-\mathrm{OH}$ (or $\mathrm{Ca}-\mathrm{OH}$ ) bond to total $\mathrm{Si}$ (or $\mathrm{Ca}$ ) atoms, \%; ${ }^{\mathrm{d}} \mathrm{The}$ ratio of the coordination number between $\mathrm{Si}$ (or $\mathrm{Ca}$ ) and $\mathrm{O}_{\mathrm{h}}$ atomic type to the total coordination number between $\mathrm{Si}$ (or $\mathrm{Ca}$ ) and $\mathrm{O}$; ${ }^{\mathrm{e}}$ The average number of $\mathrm{Si}-\mathrm{OH}$ (or $\mathrm{Ca}-\mathrm{OH}$ ) bond per $\mathrm{Si}$ (or $\mathrm{Ca}$ ) atom; ${ }^{\mathrm{f}} \mathrm{The}$ percentage of $\mathrm{OH}$ interacted with $\mathrm{Si}$ (or $\mathrm{Ca}$ ) to total $\mathrm{OH}$, including long range interaction, \%; ${ }^{\mathrm{g}} \mathrm{The}$ average number of $\mathrm{Si}(\mathrm{Ca})$ atoms interacted with $\mathrm{OH}$ per $\mathrm{OH}$; ${ }^{\mathrm{h}} \mathrm{The}$ distributed ratio of $\mathrm{OH}$ between $\mathrm{Si}-\mathrm{OH}$ and $\mathrm{Ca}-\mathrm{OH}$, calculated by the coordination number between $\mathrm{OH}$ and $\mathrm{Si}$ (or Ca), \%; iThe molar ratio of $\mathrm{H}$ atoms in the form of $\mathrm{Si}-\mathrm{OH}$ (or Ca-OH) to total $\mathrm{H}$ atoms; ${ }^{j}$ The molar ratio of $\mathrm{Ca}-\mathrm{OH}$ bonds to total $\mathrm{Ca}$ atoms, reflecting the molar ratio of $\mathrm{Ca}$ required $\mathrm{OH}$ to balance its charge to the total $\mathrm{Ca}$. 
Table 3. The distribution of $\mathrm{O}$ and $\mathrm{H}$ atoms in C-S-H

\begin{tabular}{|c|c|c|c|c|c|c|c|}
\hline $\mathrm{C} / \mathrm{S}$ & Raw materials & $\mathrm{Ca}-\mathrm{OH}^{25}$ & $\mathrm{Si}_{-} \mathrm{OH}^{25}$ & $\mathrm{H}_{2} \mathrm{O}^{25}$ & $\mathrm{Ca}-\mathrm{OH} / \mathrm{H}^{\mathrm{a}}$ & $\mathrm{Si}-\mathrm{OH} / \mathrm{H}^{\mathrm{a}}$ & $\mathrm{H}_{2} \mathrm{O} / \mathrm{H}^{\mathrm{a}}$ \\
\hline 1.85 & $\mathrm{C}_{2} \mathrm{~S}+\mathrm{H}_{2} \mathrm{O}$ & 24 & 8 & 12 & 43 & 14 & 43 \\
\hline 1.85 & $\mathrm{C}_{2} \mathrm{~S}+\mathrm{SiO}_{2}$ & 34 & 10 & 15 & 46 & 14 & 41 \\
\hline 1.77 & $\mathrm{C}_{2} \mathrm{~S}+\mathrm{H}_{2} \mathrm{O}$ & 22 & 8 & 15 & 37 & 13 & 50 \\
\hline 1.70 & $\mathrm{CaO}+\mathrm{SiO}_{2}$ & 25 & 5 & 12 & 46 & 9 & 44 \\
\hline 1.70 & $\mathrm{C}_{2} \mathrm{~S}+\mathrm{SiO}_{2}$ & 29 & 10 & 23 & 34 & 12 & 54 \\
\hline 1.56 & $\mathrm{C}_{2} \mathrm{~S}+\mathrm{H}_{2} \mathrm{O}$ & 18 & 6 & 9 & 43 & 14 & 43 \\
\hline 1.54 & $\mathrm{CaO}+\mathrm{SiO}_{2}$ & 23 & 13 & 8 & 44 & 25 & 31 \\
\hline \multicolumn{5}{|c|}{ Experimental range } & $34 \sim 46$ & $9 \sim 25$ & $31 \sim 54$ \\
\hline \multicolumn{5}{|c|}{ MD results in present work } & $15 \sim 64$ & $7 \sim 29$ & 7 78 \\
\hline
\end{tabular}

${ }^{a}$ The calculation results based on the percentage of $\mathrm{O}$ atoms. ${ }^{25}$

Table 4. The mechanical properties of C-S-H

\begin{tabular}{lcccc}
\hline model $(x)$ & $\begin{array}{c}\text { Hill's Bulk Modulus }(K) \\
(\mathrm{GPa})\end{array}$ & $\begin{array}{c}\text { Hill's Shear Modulus }(G) \\
(\mathrm{GPa})\end{array}$ & $\begin{array}{c}\text { Elastic Modulus }(M)^{\mathrm{a}} \\
(\mathrm{GPa})\end{array}$ & $\begin{array}{c}\text { Young's Modulus }(E) \\
(\mathrm{GPa})\end{array}$ \\
\hline 0.0 & 51.7 & 17.7 & 54.3 & 47.8 \\
0.4 & 53.9 & 20.7 & 61.8 & 55.1 \\
0.7 & 53.6 & 19.7 & 59.4 & 52.7 \\
1.0 & 51.9 & 18.8 & 56.8 & 50.3 \\
1.2 & 51.6 & 24.4 & 69.4 & 63.3 \\
1.5 & 46.3 & 17.9 & 53.4 & 47.7 \\
1.7 & 51.2 & 19.9 & 59.3 & 52.9 \\
Jennite & 43.0 & 26.0 & 69.0 & 66.0 \\
Tobermorite-14 & 46.0 & 39.0 & 94.0 & 51.0 \\
cCSH (core-shell force field) ${ }^{13}$ & 49.5 & 22.7 & 64.9 & 63.0 \\
cCSH (CSHFF force field) ${ }^{29}$ & 50.5 & 21.7 & 63.1 & 57.0 \\
C-S-H (indentation experiment ${ }^{30}$ & - & - & 65.0 & 59.7 \\
\hline
\end{tabular}

${ }^{a}$ The alculated results with $M=4 G(3 K+G) /(3 K+4 G)$.

on the structural and mechanical properties are different. The $x$ value show negligible influence on $\mathrm{SiO}_{4}$ polymerization, $\mathrm{RDF}, \mathrm{CN}$ between $\mathrm{Si}$ (or $\mathrm{Ca}$ ) and total $\mathrm{O}$ atoms, mean number of $\mathrm{OH}$ groups connected to individual $\mathrm{Si}$ (or $\mathrm{Ca}$ ) atoms, the distribution proportion of $\mathrm{OH}$ in $\mathrm{Si}$ (or $\mathrm{Ca}$ ) atoms, and elastic modulus $(M$ and $E$ ). These results are consistent with those reported in literatures. ${ }^{9,13,22-24,29,30}$ However, $\mathbf{Q}^{\mathrm{n}}$ distribution, MCL, polymerization degree of $\mathrm{SiO}_{4}$, and $\mathrm{CN}$ between $\mathrm{Si}$ (or $\mathrm{Ca}$ ) atoms and three types of $\mathrm{OH}$ are distinctly influenced by the $x$ value. When $x$ varies in the range of $0.7 \sim 1.2$, these results agree well with the reported theoretical and experimental results. ${ }^{9,13,22-24,27,31}$ Therefore, the amorphous $(\mathrm{CaO})_{1.7}\left(\mathrm{SiO}_{2}\right)(\mathrm{OH})_{2 x}\left(\mathrm{H}_{2} \mathrm{O}\right)_{1.8-x}(x=0.7 \sim 1.2)$ models constructed by using the Monte Carlo method based on basic atomic units are rational for investigation of the microstructure and mechanical properties of C-S-H.

For the models with different $x$ value, the percentage of $\mathrm{H}$ atoms in $\mathrm{Ca}-\mathrm{OH}, \mathrm{Si}-\mathrm{OH}$, and water molecules for $\mathrm{C}-\mathrm{S}-\mathrm{H}$ are about $26 \% \sim 45 \%$, $13 \% \sim 22 \%$, and $61 \% \sim 33 \%$, respectively. The chemical formula for the $\mathrm{C}-\mathrm{S}-\mathrm{H}$ of $x=1.0$ can be expressed as:

$0.67\left(\mathrm{Ca}(\mathrm{OH})_{2}\right) \bullet 1.03(\mathrm{CaO}) \bullet 0.67\left(\mathrm{SiO}_{2}\right) \bullet 0.33\left(\mathrm{SiO}(\mathrm{OH})_{2}\right) \bullet 0.80\left(\mathrm{H}_{2} \mathrm{O}\right)$

This chemical formula is similar to that of natural Jennite: ${ }^{30}$

0.66 $\left(\mathrm{Ca}(\mathrm{OH})_{2}\right) \bullet \mathbf{0 . 8 4}(\mathrm{CaO}) \cdot \mathbf{0 . 8 3}\left(\mathrm{SiO}_{2}\right) \cdot \mathbf{0 . 1 7}\left(\mathrm{SiO}(\mathrm{OH})_{2}\right) \cdot \mathbf{1 . 0}\left(\mathrm{H}_{2} \mathrm{O}\right)$.
Therefore this amorphous C-S-H model in this work is characterized by Jennite-like microstructure.

\section{CONCLUSIONS}

It is of great significance to grasp the existing form and distribution of hydrogen in $\mathrm{C}-\mathrm{S}-\mathrm{H}$ for understanding the microstructure and mechanical properties of C-S-H. In this work, a new strategy of C-S-H models construction based on the basic units of $\mathrm{Ca}, \mathrm{Si}, \mathrm{O}, \mathrm{OH}$ and $\mathrm{H}_{2} \mathrm{O}$ is presented to explore the microstructure of C-S-H and hydrogen atom distribution in $\mathrm{C}-\mathrm{S}-\mathrm{H}$ by combining MD simulation with ClayFF force field. It has been shown that the amorphous C-S-H models can reach equilibrium quickly and reproduce the microstructure and mechanical properties of C-S-H. This provides a new idea for constructing theoretical model for computational study of C-S-H on a larger molecular scale.

For the $\mathrm{Ca}_{1.7} \bullet \mathrm{Si} \bullet(\mathrm{O})_{3.7-x} \bullet(\mathrm{OH})_{2 x} \bullet\left(\mathrm{H}_{2} \mathrm{O}\right)_{1.8-x}$ model $(x=0.7 \sim 1.2)$, the simulated $\mathrm{Q}^{\mathrm{n}}, \mathrm{RDF}, \mathrm{CN}$ and elastic modulus are consistent with those reported in previous theoretical and experimental works. In the $\mathrm{C}-\mathrm{S}-\mathrm{H}$, the percentages of hydrogen atom in $\mathrm{Ca}-\mathrm{OH}, \mathrm{Si}-\mathrm{OH}$, and $\mathrm{H}_{2} \mathrm{O}$ are determined to be about $26 \% \sim 45 \%, 13 \% \sim 22 \%$, and $61 \% \sim 33 \%$, respectively.

The chemical structural formula of C-S-H of $x=1.0$ can be expressed as: 
$\mathbf{0 . 6 7}\left(\mathrm{Ca}(\mathrm{OH})_{2}\right) \cdot \mathbf{1 . 0 3}(\mathrm{CaO}) \bullet \mathbf{0 . 6 7}\left(\mathrm{SiO}_{2}\right) \bullet \mathbf{0 . 3 3}\left(\mathrm{SiO}(\mathrm{OH})_{2}\right) \bullet \mathbf{0 . 8 0}\left(\mathrm{H}_{2} \mathrm{O}\right)$,

which excellent matches the structural characteristics of natural jennite $(\mathrm{C} / \mathrm{S}=1.5)$.

\section{SUPPLEMENTARY MATERIAL}

The parameters in the ClayFF force field, the results about the adequacy of simulation time and reproducibility of modelling method, the layered C-S-H structure, the MSD of water molecules in deferent $\mathrm{C}-\mathrm{S}-\mathrm{H}$ models, the proportional variation of three types of $\mathrm{H}$ atoms in $\mathrm{C}-\mathrm{S}-\mathrm{H}$, and the awk code for calculating $\mathrm{Q}^{\mathrm{n}}$ in this study are available on http://quimicanova.sbq.org.br in the form of a PDF file with free access.

\section{ACKNOWLEDGEMENTS}

This manuscript was funded by the Talent Introduction Science Research Fund of Xiangnan University.

\section{REFERENCES}

1. Allen, A. J.; Thomas, J. J.; Jennings, H. M.; Nat. Mater. 2007, 4, 311.

2. Rawal, A.; Smith, B. J.; Athens, G. L.; Edwards, C. L.; Roberts, L.; Gupta, V.; Chmelka, B. F; J. Am. Chem. Soc. 2010, 21, 7321.

3. Thomas, J. J.; FitzGerald, S. A.; Neumann, D. A.; Livingston, R. A.; J. Am. Ceram. Soc. 2001, 8, 1811.

4. Dharmawardhana, C.; Bakare, M.; Misra, A.; Ching, W. Y.; J. Am. Ceram. Soc. 2016, 6, 2120.

5. Cong, X. D.; Kirkpatrick, R. J; Adv. Cem. Based Mater. 1996, 3, 133.

6. Yu, P.; Kirkpatrick, R. J.; Poe, B.; McMillan, P.F.; Cong, X. D.; J. Am. Ceram. Soc. 1999, 3, 742.

7. Yang, J.; Hou, D. S.; Ding, Q. J.; ACS Sustainable Chem. Eng. 2018, 7, 9403.

8. Zhou, Y.; Hou, D.; Geng, G.; Feng, P.; Yu, J.; Jiang, J.; Phys. Chem. Chem. Phys. 2018, 12, 8247.

9. Dolado, J. S.; Griebel, M.; Hamaekers, J.; J. Am. Ceram. Soc. 2007, 90, 3938.

10. Richardson, I. G.; Cem. Concr. Res. 1999, 8, 113.

11. Rimsza, J. M.; Jones, R. E.; Criscenti, L. J.; Langmuir 2017, 15, 3882.
12. Mitra, N.; Sarkar, P. K.; Prasad, D.; Phys. Chem. Chem. Phys. 2019, 21, 11416.

13. Pellenq, R. J.-M.; Kushima, A.; Shahsavari, R.; Van Vliet, K. J.; Buehle, M. J.; Yip, S.; Ulm, B. S.; Proc. Natl. Acad. Sci. U. S. A. 2009, 38, 16102.

14. Cygan, R. T.; Liang, J. J.; Kalinichev, A. G.; J. Phys. Chem. B 2004, 4, 1255 .

15. Mishra, R. K.; Mohamed, A. K.; Geissbühler, D.; Manzano, H.; Jamil, T.; Shahsavari, R.; Kalinichev, A.G.; Galmarini, S.; Tao, L.; Heinz, H.; Pellenq, R.; van Duin, A. C.T.; Parker, S. C.; Flatt, R. J.; Bowen, P.; Cem. Concr. Res. 2017, 102, 68.

16. Accelrys Software inc.; Materials Studio Release Notes, Release 5.0, San Diego, Accelrys Software Inc., 2009.

17. Galmarini, S.; Aimable, A.; Ruffray, N.; Bowen, P.; Cem. Concr. Res. 2011, 12, 1330 .

18. Abramov, A.; Iglauer, S.; Langmuir 2019, 17, 5746.

19. Bonaccorsi, E; Merlino, S.; Taylor, H. F. W.; Cem. Concr. Res. 2004, 9 , 1481 .

20. Nose, S.; Mol. Phys. 1984, 2, 255.

21. Karasawa, N.; Goddard, W. A.; Macromolecules 1992, 26, 7268.

22. Mendes, A.; Gates, W. P.; Sanjayan, J. G.; Collins, F.; Mater. Struct. 2011, 10, 1773

23. Goñi Elizalde, S.; Puertas, F.; Hernández, M. S.; Palacios, M.; Guerrero, A.; Dolado, J. S.; Zanga, B.; Baroni, F.; J. Therm. Anal. Calorim. 2010 , 102, 965 .

24. Qomi, M. J. A.; Ulm, F. J.; Pellenq Roland, J. M.; J. Am. Ceram. Soc. 2012, 3, 1128.

25. Faucon, P.; Delaye, J. M.; Virlet, J.; Jacquinot, J. F.; Adenot, F.; Cem. Concr. Res. 1997, 10, 1581.

26. Hidalgo, A.; Petit, S.; Domingo, C.; Alonso, C.; Andrade, C.; Cem. Concr. Res. 2007, 1, 63.

27. Thomas, J. J.; Chen, J. J.; Jennings, H. M.; Neumann, D. A.; Chem. Mater. 2003, 20, 3813.

28. Cong, X. D.; Kirkpatrick, R.; J. Am. Ceram. Soc. 1996, 6, 1585.

29. Shahsavari, R.; Pellenq Roland, J. M.; Ulm, F. J.; Phys. Chem. Chem. Phys. 2011, 13, 1002.

30. Constantinides, G.; Ulm, F.-J.; J. Mech. Phys. Solids 2007, 1, 64.

31. Wang, L.; He, Z.; Zhang, B.; Cai, X. H.; J. Chin. Ceram. Soc. 2010, 11, 2212 . 